\title{
Some errors in the determination of nitrogen retention of sheep by nitrogen balance studies
}

\author{
By A. K. MAR'TIN \\ Hannah Dairy Research Institute, Ayr \\ (Received 31 August 1965-Accepted 27 Fanuary 1966)
}

\begin{abstract}
1. Loss of $\mathrm{NH}_{3} \mathrm{~N}$ from faeces and urine between voiding and collection and also losses in expired air, eructed gas and from the skin of wether sheep 2-3 years old given a ration of 400 , 700 , 1000 or $1300 \mathrm{~g}$ dried grass/day have been measured. 2. Losses of $\mathrm{NH}_{3}$ from faeces were negligible, and the loss from urine depended on the temperature and $\mathrm{pH}$ at which it was collected. Collection at neutral $\mathrm{pH}$ resulted in losses of up to $9.7 \%$ of the urinary $\mathrm{N}$ as $\mathrm{NH}_{3}$ gas if an acid trap were not incorporated in the collection apparatus. The average loss of $\mathrm{N}$ on collection of urine at $\mathrm{pH}$ values below $2 \cdot 0$ was $\mathrm{I} \cdot 33 \%$ when the ambient temperature was between 2.5 and $28^{\circ}$, and $0.97 \%$ when it was between $\mathrm{I}_{5}$ and $18^{\circ} .3$. Very little $\mathrm{NH}_{3}$ was lost in expired air or eructed gas, but when total $\mathrm{NH}_{3}$ loss other than that from urine was determined, an average loss of $3.14 \pm 0.55 \mathrm{mg} \mathrm{N} / \mathrm{kg}$ body-weight per day was found. This loss was independent of food intake and larger than the loss of $\mathrm{N}$ in suint which was estimated to range from 0.59 to $2.55 \mathrm{mg} \mathrm{N} / \mathrm{kg}$ body-weight per day with the rations given. It was concluded that the larger losses found in some experiments were due to splashing of urine on to the fleece during collection and subsequent loss of this urine $\mathrm{N}$ as $\mathrm{NH}_{3}$. It was shown that the losses of $\mathrm{NH}_{3} \mathrm{~N}$ due to errors in urine collection and failure to consider dermal losses ranged between $\mathrm{I} \cdot 2$ and $2.6 \%$ of the total determined losses in faeces and urine for sheep fed on a variety of diets and that the losses varied inversely with intake of $\mathrm{N}$.
\end{abstract}

Recently doubt has been expressed concerning the validity of the use of nitrogen balance techniques to measure protein retention. Reports of long-term positive $N$ balances in the absence of body-weight gains have been discussed by Allison \& Bird ( 1964$)$ in relation to dermal losses of N. Large discrepancies obtained in some experiments between the results for $\mathrm{N}$ retention as assessed by simultaneous carcass analysis and those obtained by $\mathrm{N}$ balance determinations, in which the latter may exceed the former by up to $40 \%$, have been discussed by Nehring (1957) and by Bock, Nehring, Schiemann, Hovorka, Horszczaruk \& Angelowa (1964). Underestimation of carcass $\mathrm{N}$ was found to be responsible for much of the error, but retention was nearly always overestimated by $\mathrm{N}$ balance even when reliable methods of determining carcass $\mathrm{N}$ were used. Similar results have been reported by other workers, e.g. Henry (1965) and Butterworth (1963).

In this laboratory $\mathrm{N}$ balances are determined routinely during energy exchange studies with sheep. Sheep are harnessed for separate collection of faeces and urine, and urine is collected by the method described by Wainman \& Paterson ( 1963 ). Incorporation of an acid trap between the urine reservoir and the continuously running pump used to aspirate urine into the reservoir in this apparatus was found to result in the trapping of between 0.02 and $0.77 \mathrm{~g}$ ammonia $\mathrm{N}$ daily which would otherwise have been lost (Martin, I965, unpublished). This loss represented from 0.1 to $9.7 \%$ of the $\mathrm{N}$ collected in the urine reservoir.

In view of this loss of $\mathrm{N}$, a study was made of the factors affecting it and an ex- 
amination made of routes of $\mathrm{N}$ loss other than those of faeces and urine. Ammonia was considered the most likely volatile form in which $\mathrm{N}$ would be lost, and measurements have been made of dermal, respiratory and ruminal losses of this gas.

\section{EXPERIMENT AL}

Determination of urinary volatile $\mathrm{NH}_{3}$

The apparatus used for the collection of sheep urine is illustrated in Fig. I. The urine pump runs continuously so a stream of air is drawn over the urine in the reservoir throughout the collection period. As ruminant urine is generally slightly alkaline in reaction this must lead to a loss of $\mathrm{NH}_{3} \mathrm{~N}$ unless the urine preservative used reduces the $\mathrm{pH}$ well below 7 .

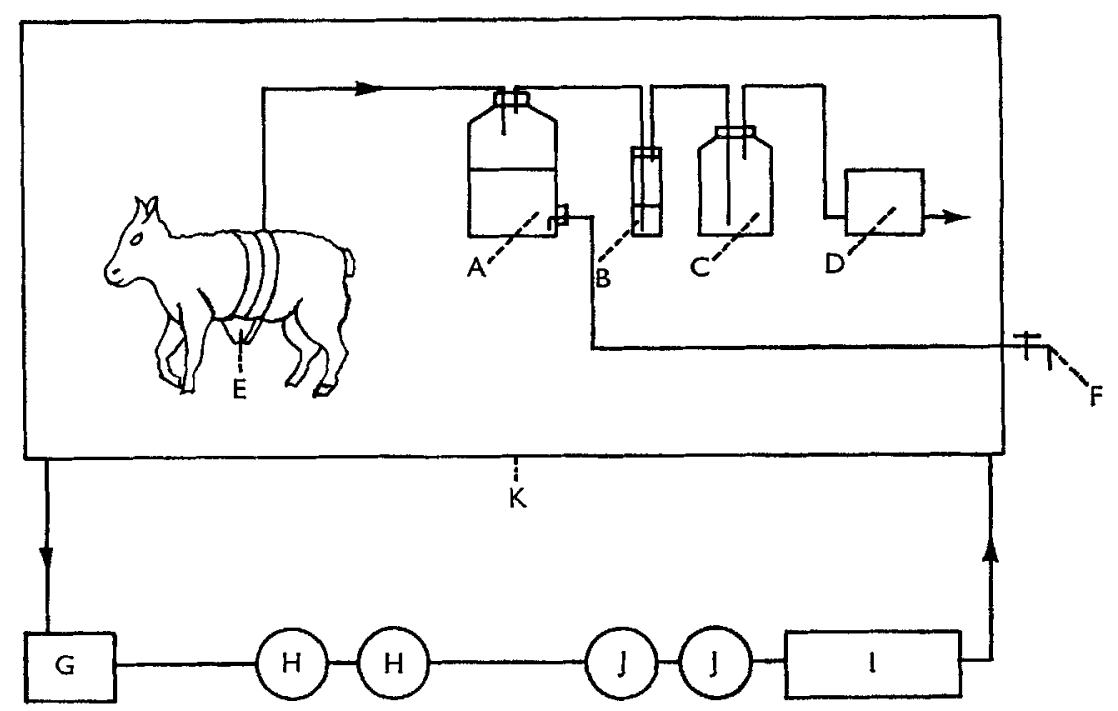

Fig. r. Diagram showing the apparatus used to collect urine from sheep and the position of the acid trap used in determination of the total $\mathrm{NH}_{3}$ lost by sheep in a respiration chamber. $\mathrm{A}$, urine reservoir; $\mathrm{B}$, urine volatile $\mathrm{NH}_{3}$ trap; $\mathrm{C}$, calcium chloride drying bottle; $\mathrm{D}$, urine pump; E, urine funnel; $F$, urine drain tap; $G$, blower circulating air from the respiration chamber through the absorption train; $\mathrm{H}, 5 \mathrm{l}$. flat-bottomed Pyrex flasks containing $\mathrm{I}_{25} \mathrm{l} . \mathrm{N}-\mathrm{H}_{2} \mathrm{SO}_{4}$ to absorb $\mathrm{NH}_{3}$ lost from sheep; I, silica gel tubes; J, Polythene bottles containing $40 \%(\mathrm{w} / \mathrm{v})$ $\mathrm{KOH} ; \mathrm{K}$, wall of respiration chamber.

Two different types of trap were used to absorb $\mathrm{NH}_{3}$. One consisted of a Pyrex boiling-tube three-quarters filled with granular pumice soaked in $18 \mathrm{~N}$-sulphuric acid. The pumice was ground to pass a number 6 mesh sieve but held by a number 16 mesh sieve (British Drug Houses, Poole, Dorset). The tube was fitted with a rubber bung with a long entry and a short exit tube. The other form of $\mathrm{NH}_{3}$ trap consisted of a series of four tubes each containing ${ }_{5} \mathrm{ml} 2 \%(\mathrm{w} / \mathrm{v})$ boric acid and brom-cresol green indicator. In the former method $\mathrm{NH}_{3}$ was distilled into boric acid indicator solution and titrated, and in the latter it was titrated directly. Boric acid was not used as an $\mathrm{NH}_{3}$ trap when the ambient temperature exceeded $30^{\circ}$. 


\section{Losses of $\mathrm{NH}_{3}$ during urine collection.}

To find the losses of $\mathrm{NH}_{3}$ when urine is collected by the method of Wainman $\&$ Paterson (1963) the following experiments were made. First, the efficacy of preservatives was checked and losses of $\mathrm{NH}_{3}$ from the reservoir determined. Two urine preservatives were used. The first was a mercuric chloride-potassium dichromate mixture (12.5 and $87.5 \mathrm{~g}$ respectively per 1 . distilled water), which had no effect on urine $\mathrm{pH}$; the second was sulphuric acid used in sufficient quantity (I8 $\mathrm{ml} \mathrm{I} 8 \mathrm{~N}$ $\mathrm{H}_{2} \mathrm{SO}_{4}$ per 1. urine) to maintain urine $\mathrm{pH}$ below $2 \cdot 0$.

Into six pairs of $500 \mathrm{ml}$ conical flasks were pipetted $200 \mathrm{ml}$ of a sample of sheep or calf urine. To one flask of each pair was added $5 \mathrm{ml}$ of the mercuric chloridepotassium-dichromate preservative and to the other $3.6 \mathrm{ml}$ of $18 \mathrm{~N}-\mathrm{H}_{2} \mathrm{SO}_{4}$. Each flask was fitted with a bung with two glass tubes, one leading to an atmospheric $\mathrm{NH}_{3}$ trap of dilute acid and the other to a series of $\mathrm{NH}_{3}$ absorption tubes containing $2 \%(\mathrm{w} / \mathrm{v})$ boric acid and brom-cresol green indicator. Duplicate pairs of flasks were incubated at $4^{\circ}, 20^{\circ}$ and $30^{\circ}$ for $24 \mathrm{~h}$. During this time a small pump drew air through the acid trap over the urine and through the $\mathrm{NH}_{3}$ traps. $\mathrm{NH}_{3}$ was determined by titration with $0.01 \mathrm{~N}-\mathrm{HCl}$.

Secondly, to check losses of $\mathrm{NH}_{3}$ from the collecting equipment attached to the sheep, similar experiments were made in which the rubber funnel, used to collect urine from the sheep, together with its associated tubing, was attached to the collecting flask. Acid preservative was added to one pair of flasks and mercuric chloridepotassium dichromate preservative to the other pair. Urination was simulated by adding ten $20 \mathrm{ml}$ amounts of urine to the funnel at 30 min intervals. The loss of $\mathrm{NH}_{3}$ over $24 \mathrm{~h}$ periods was determined.

\section{Loss of $\mathrm{NH}_{3} \mathrm{~N}$ from faeces}

A desiccator was used as a diffusion unit. An evaporating dish containing $39 \%(\mathrm{v} / \mathrm{v})$ $\mathrm{H}_{2} \mathrm{SO}_{4}$ was placed in the centre surrounded by $100 \mathrm{~g}$ of freshly collected faeces pellets. The desiccator was closed and incubated for $24 \mathrm{~h}$ at $4^{\circ}, 20^{\circ}$ or $37^{\circ}$.

\section{Losses of $\mathrm{NH}_{3}$ in expired air}

Four experiments were made with a rumen-fistulated sheep and one with an intact sheep. The fistulated sheep received a continuous intraruminal drip of urea for $2 \mathrm{~h}$ before and during collection of expired air plus eructed gas. The concentration of urea in the solution infused was $0.014 \mathrm{~g}$ urea $\mathrm{N} / \mathrm{ml}$ and it was infused at an average rate of $\mathrm{i} 87 \mathrm{ml} / \mathrm{h}$. The expired air was collected by means of a closely fitting face mask into a series of carefully cleaned Douglas bags. These were evacuated through a series of six bubblers containing $20 \mathrm{mI} \mathrm{N}-\mathrm{H}_{2} \mathrm{SO}_{4}$ to absorb $\mathrm{NH}_{3}$ and then through a wetgas meter to measure the volume of expired air. Expired air uncontaminated by eructed gas was collected from an intact sheep anaesthetized with Nembutal (Abbot Laboratories Ltd) by tracheal intubation. Collection periods were of $3-4 \mathrm{~h}$ for all the sheep. 


\section{Determination of $\mathrm{NH}_{3}$ in dilute sulphuric acid}

To determine the $\mathrm{NH}_{3} \mathrm{~N}$ lost in expired air, a modification of the method of Tetlow $\&$ Wilson (1964) was used. This method depends on the formation of a blue indophenol dye when $\mathrm{NH}_{3}$ reacts with sodium phenate and sodium hypochlorite in alkaline solution. The reagents were, with the exception of sodium phenate, prepared as described by Crowther \& Large (1956) and the method was found satisfactory for concentrations of $\mathrm{NH}_{3}$ down to $0 . \mathrm{I} \mu \mathrm{g} \mathrm{NH}_{3} \mathrm{~N} / \mathrm{ml}$. The development of the indophenol blue colour is very sensitive to small changes in $\mathrm{NaOH}$ concentration and for this reason $6.50 \mathrm{~N}$ in place of $6.75 \mathrm{~N}-\mathrm{NaOH}$ was used in the preparation of sodium phenate. This change resulted in an increase of $I 1 \%$ in sensitivity. Since colour development is dependent on the final concentration of $\mathrm{NaOH}$, the acid solutions used to absorb $\mathrm{NH}_{3}$ were carefully neutralized to $\mathrm{pH} 7 \cdot 0$ with $\mathrm{NaOH}$ before analysis. All glassware was stored between determinations in a $0.05 \%(\mathrm{v} / \mathrm{v})$ solution of an alkaline detergent (RBS 25; Medical \& Pharmaceutical Products, Shoreham, Sussex).

\section{Determination of total $\mathrm{NH}_{3}$ loss from sheep}

To measure this loss, sheep were placed in a newly painted closed-circuit respiration chamber (Wainman \& Blaxter, 1958). The sheep used were wethers from 2 to 3 years old, of the Kent or Hampshire breeds. Four groups of sheep, R, W, B and Y were given 400,700 , 1000 and $1300 \mathrm{~g}$ respectively of a good-quality dried grass daily. Air from the chamber was passed through an absorption train consisting of two 5 l. flat-bottomed Pyrex flasks each containing $\mathrm{I}_{25} \mathrm{l}$ l. $\mathrm{N}-\mathrm{H}_{2} \mathrm{SO}_{4}$, then through two large Polythene bottles containing $40 \%$ (w/v) KOH and then through four cylinders containing silica gel, from the last of which the gas was returned to the respiration chamber. Air-flow through the train was maintained at $75 \mathrm{l} / \mathrm{min}$ for the $24 \mathrm{~h}$ of each experiment. In all the experiments it was found that the first acid-containing flask retained $99 \%$ of the $\mathrm{NH}_{3}$ absorbed in the two flasks.

To determine the efficiency of this method of measuring $\mathrm{NH}_{3}$ loss, $\mathrm{NH}_{3}$ was continuously released over a $24 \mathrm{~h}$ period in the chamber and the percentage recovery in the absorption train measured. A solution of dilute $\mathrm{NH}_{4} \mathrm{Cl}$ was infused as a continuous drip into a flask containing $40 \%(\mathrm{w} / \mathrm{v}) \mathrm{KOH}$ solution aerated by a small pump. Any $\mathrm{NH}_{3}$ not released from the $\mathrm{KOH}$ and also $\mathrm{NH}_{3}$ trapped in the acid flasks were determined colorimetrically as described above. During these recovery experiments and in studies of $\mathrm{NH}_{3}$ loss from sheep, the volatile $\mathrm{NH}_{3}$ traps were in place and the urine pumps switched on. In these experiments urinary volatile $\mathrm{NH}_{3}$ was also trapped in $\mathrm{N}-\mathrm{H}_{2} \mathrm{SO}_{4}$ and determined colorimetrically.

\section{The $N$ content of suint}

The $\mathrm{N}$ present in suint obtained by repeated water extraction of the inner half of the fleece staple from mid-side wool of Down Cross sheep was determined. $\mathrm{N}$ was determined by the macro-Kjeldahl method, $\mathrm{NH}_{3}$ and urea by the method of Van Slyke \& Cullen (I9I4), protein $\mathrm{N}$ after precipitation with $5 \%$ zinc sulphate and 0.3 $\mathrm{N}-\mathrm{NaOH}$, and non-protein $\mathrm{N}$ by difference. 


\section{$\mathrm{NH}_{3}$ loss from skin and fleece}

Loss of $\mathrm{NH}_{3}$ from skin and fleece was measured by covering a $500 \mathrm{~cm}^{2}$ area of a sheep's back with a tin box shaped to fit as closely as possible to the skin. The box was painted inside and fitted with an entry and exit tube in opposite corners. By means of a small pump, air was drawn through the box and through a series of four tubes containing $15 \mathrm{ml} \mathrm{N}-\mathrm{H}_{2} \mathrm{SO}_{4}$ to absorb $\mathrm{NH}_{3}$, and then through a flow-meter (o-51./min) and drying bottle (calcium chloride). A similar box was painted, fitted with a lid and entry and exit tubes and connected to another pump in a similar way. The flow-rates through the two boxes were adjusted to be the same and the air intake tube of the control box was kept in a position close to that of the air intake tube of the box on the fleece. $\mathrm{NH}_{3}$ was determined in the two sets of tubes colorimetrically, the difference representing $\mathrm{NH}_{3}$ loss from the skin and fleece.

\section{RESULTS}

\section{$\mathrm{NH}_{3}$ loss from faeces}

Incubation of $100 \mathrm{~g}$ faeces at $4^{\circ}, 20^{\circ}$ and $37^{\circ}$ resulted in a recovery of not more than $4 \mu \mathrm{gH}_{3} \mathrm{~N} / 24 \mathrm{~h}$.

\section{Urinary volatile $\mathrm{NH}_{3}$}

Volatile $\mathrm{NH}_{3} \mathrm{~N}$ loss was determined for sixteen samples of sheep urine collected over a $24 \mathrm{~h}$ period into $10 \mathrm{ml}$ of mercuric chloride-potassium dichromate preservative solution. The average $\mathrm{pH}$ was 8.75 with a range of from 6.92 to 9.57 . Presumably some hydrolysis of urea must have occurred during the $24 \mathrm{~h}$ collection periods to give the higher $\mathrm{pH}$ values. Not surprisingly, losses of volatile $\mathrm{NH}_{3}$ were large, ranging from $0.17 \mathrm{~g}$ to $0.70 \mathrm{~g} \mathrm{NH}_{3} \mathrm{~N} /$ day or 0.69 to $9.72 \%$ of the total urinary $\mathrm{N}$ collected.

Table I. Effect of temperature and $p H$ on the loss in $24 h$ of volatile $\mathrm{NH}_{3}$ from sheep and calf urine

\begin{tabular}{|c|c|c|c|c|c|c|c|}
\hline \multirow{3}{*}{ Animal } & \multirow{3}{*}{$\begin{array}{l}\mathrm{N} \text { contained } \\
\text { in } 200 \mathrm{ml} \\
\text { urine }(\mathrm{g})\end{array}$} & \multicolumn{6}{|c|}{$\begin{array}{c}\text { Loss of } \mathrm{N}_{\text {as }} \mathrm{NH}_{3} \text { (as \% of total } \mathrm{N} \\
\text { initially present) }\end{array}$} \\
\hline & & \multicolumn{3}{|c|}{$\mathrm{pH}+0-2 \cdot 0$} & \multicolumn{3}{|c|}{$\mathrm{pH} 7 \cdot 5-8 \cdot 5$} \\
\hline & & $4^{\circ}$ & $20^{\circ}$ & $30^{\circ}$ & $4^{\circ}$ & $20^{\circ}$ & $30^{\circ}$ \\
\hline Sheep & $I \cdot 83$ & 0.00 & O.I I & 0.27 & 0.63 & $2 \cdot 54$ & $3 \cdot 87$ \\
\hline Calf & 0.80 & 0.00 & 0.00 & 0.02 & I.70 & 3.16 & 6.75 \\
\hline
\end{tabular}

The results of the laboratory experiments, conducted as described on p. $3^{27}$ to find the effects of the temperature and $\mathrm{pH}$ of the urine on volatile $\mathrm{NH}_{3}$ loss, are shown in Table r. Extremely little $\mathrm{NH}_{3}$ was lost from acid-preserved urine whatever the temperature, but from alkaline urine an increasing amount of $\mathrm{NH}_{3}$ was lost with increasing temperature, the loss at $30^{\circ}$ being $6.75 \%$ of the total $\mathrm{N}$ initially present.

In routine $\mathrm{N}$ balance determinations with sheep a measurable amount of $\mathrm{NH}_{3}$ was found in the acid trap even when an acid urine preservative was used. In ${ }_{57}$ urine collections from sheep, ninety-one conducted at temperatures between 25 and $30^{\circ}$ 
and sixty-six between 15 and $18^{\circ}$, the amounts of volatile $\mathrm{NH}_{3}$ lost, expressed as percentages of the total $\mathrm{N}$ recovered in the urine reservoir, were $1 \cdot 33 \pm 0.10$ and $0.97 \pm 0.12$ (means and standard errors) at the higher and lower temperatures respectively. The coefficients of variation were very large, 68.3 and roI.5\% respectively.

There was then an appreciable loss of volatile $\mathrm{NH}_{3}$ when urine was collected from sheep in spite of maintaining the $\mathrm{pH}$ of urine in the reservoir below 2.0. Drawing air over similar sheep urine samples in laboratory experiments resulted in a negligible $\mathrm{NH}_{3}$ loss. The difference must be due to the fact that urine was aspirated from the urine funnel into the urine reservoir each time the sheep urinated during collection from the animal, whereas in the laboratory experiments urine was placed in the flask containing the urine preservative before the experiment started. The effect of aspiration of urine into the reservoir on volatile $\mathrm{NH}_{3}$ loss was tested in further laboratory experiments in which urine was either pipetted directly into the flask containing the preservative or the same volume aspirated into the flask in ten equal aliquots. Volatile $\mathrm{NH}_{3}$ loss without aspiration of urine was determined over a $24 \mathrm{~h}$ period as described in the experimental section. The results pertaining to a dilute calf urine are presented in Table 2 . Loss of volatile $\mathrm{NH}_{3}$ from urine aspirated into acid was more than twenty times greater than that from urine pipetted into the acid ( 0.08 compared with $\mathrm{I}^{-} 72 \mathrm{mg} \mathrm{N}$ ). Much larger amounts of volatile $\mathrm{NH}_{3}$ were lost from alkaline urine, and here also aspiration of urine increased volatile $\mathrm{NH}_{3}$ loss from 14.9 to $2.2 .5 \mathrm{mg} \mathrm{N}$ / $24 \mathrm{~h}$ which was equivalent to from 2.4 to $3.7 \%$ of the urine $\mathrm{N}$ initially present in the sample.

Table 2. Effect of drawing urine from a urine funnel into a reservoir compared with placing the urine directly in the reservoir on the volatile $\mathrm{NH}_{3}$ loss from a calf urine sample. The preservative used was either acid $(p H 2 \cdot 0)$ or mercuric chloride-potassium dichromate $(p H 7 \cdot 5)$

\begin{tabular}{|c|c|c|c|c|}
\hline $\mathrm{pH}$ & $\begin{array}{l}200 \mathrm{ml} \text { urine in } \\
\text { flask, or added in } \\
\text { ten equal } \\
\text { portions to the } \\
\text { urine funnel }\end{array}$ & $\begin{array}{c}\text { Volatile } \mathrm{NH}_{3} \mathrm{~N} \\
\text { lost } \\
(\mathrm{mg} \mathrm{N} / 24 \mathrm{~h})\end{array}$ & $\begin{array}{c}\text { Volatile } N \\
\text { lost (as \% of } \\
\text { total } N \text { added) }\end{array}$ & $\begin{array}{c}\text { Volatile } \mathrm{N} \\
\text { lost (as \% of } \\
\mathrm{NH}_{3} \mathrm{~N} \text { added) }\end{array}$ \\
\hline $2 \cdot 0$ & Flask & 0.08 & $<0.01$ & 0.01 \\
\hline $2 \cdot 0$ & Funnel & $I \cdot 72$ & 0.28 & $2 \cdot 30$ \\
\hline 7.5 & Flask & I 4.89 & $2 \cdot 44$ & 19.93 \\
\hline $7 \cdot 5$ & Funnel & $22 \cdot 54$ & 3774 & 30.17 \\
\hline
\end{tabular}

$200 \mathrm{ml}$ urine contained $0.610 \mathrm{~g} \mathrm{~N}, 0.075 \mathrm{~g} \mathrm{NH}_{3} \mathrm{~N}$ and $0.352 \mathrm{~g}$ urea $\mathrm{N}$.

\section{$\mathrm{NH}_{3}$ in expired air}

Urea was infused into the rumen of a sheep with a permanent cannula on three occasions and expired air plus eructed gas collected as already described. The concentrations of $\mathrm{NH}_{3}$ in rumen liquor averaged for the periods of infusion were I I4, 60 and $68 \mathrm{mg} \mathrm{NH} \mathrm{NH}_{3} \mathrm{~N} / 100 \mathrm{ml}$. The collection periods were of 290,260 and $210 \mathrm{~min}$ respectively during which time $0.177,0.148$ and $0.429 \mathrm{mg} \mathrm{NH}_{3} \mathrm{~N}$ were collected. This was equivalent to a loss of $0.036,0.043$ and $0.123 \mathrm{mg} \mathrm{NH} / \mathrm{N} / \mathrm{h}$ respectively during the collection periods. From expired air alone collected from an intact sheep through a 
McGill tube, the loss of $\mathrm{NH}_{3} \mathrm{~N}$ was $0.149 \mathrm{mg}$ in $240 \mathrm{~min}$ or $0.037 \mathrm{mg} \mathrm{NH}_{3} \mathrm{~N} / \mathrm{h}$. There was no apparent relationship between rumen $\mathrm{NH}_{3}$ concentration and the loss of $\mathrm{NH}_{3}$ in eructed plus expired air. All the values were corrected for $\mathrm{NH}_{3}$ present in inspired air.

\section{Determination of total $\mathrm{NH}_{3}$ loss from sheep}

Preliminary recovery experiments when $\mathrm{NH}_{3}$ was released in the respiration chamber showed that only about half of it was recovered in a $24 \mathrm{~h}$ period. Complete repainting of the interior of the chamber and cage and thorough washing of the pipework of the respiration apparatus did not improve the recovery.

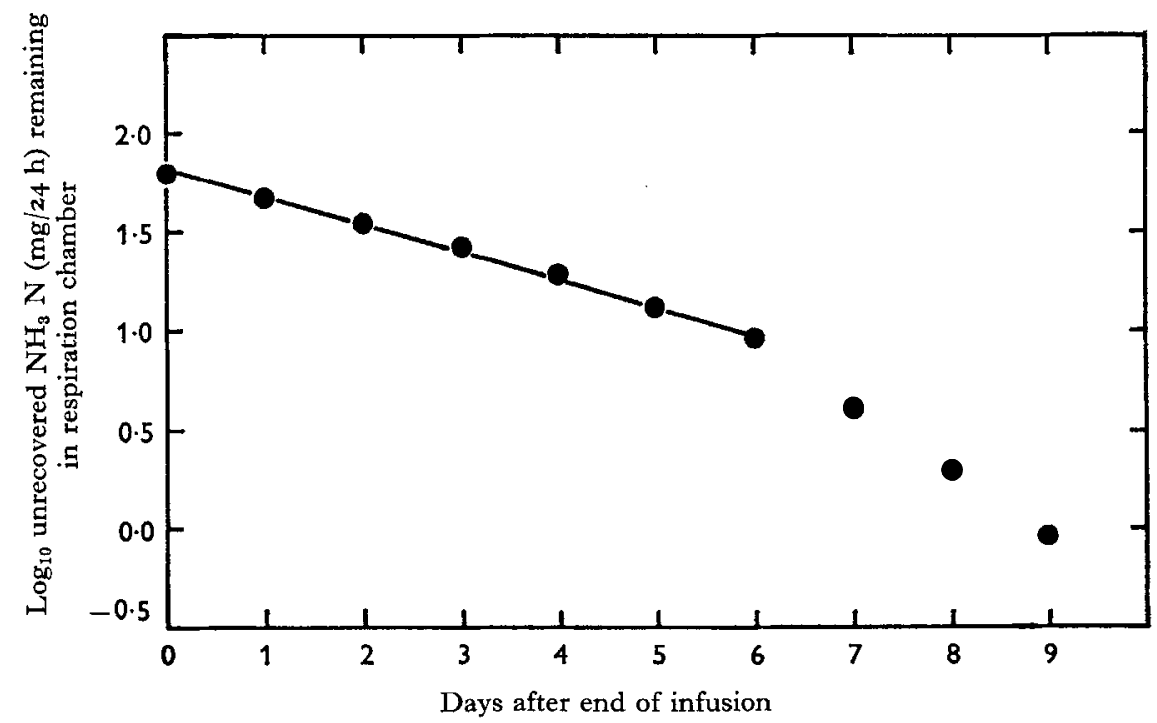

Fig. 2. The $\log _{10}$ of the amount of $\mathrm{NH}_{3} \mathrm{~N}$ unrecovered after its release into a respiration chamber. A solution of $\left(\mathrm{NH}_{4}\right)_{2} \mathrm{SO}_{4}$ was infused into $50 \%(\mathrm{w} / \mathrm{v}) \mathrm{NaOH}$ or $40 \%(\mathrm{w} / \mathrm{v}) \mathrm{KOH}$ for a $24 \mathrm{~h}$ period. The respiration chamber remained closed during the period of infusion and for the I I days after its termination. Complete recovery was obtained 9 days after the infusion stopped.

In Fig. 2 the results of a recovery experiment in which $\mathrm{NH}_{3}$ was infused into $40 \%(\mathrm{w} / \mathrm{v}) \mathrm{KOH}$ as a continuous drip for $24 \mathrm{~h}$ are given. The infusion was then stopped and the chamber run without being opened for a further I I days. The successive $24 \mathrm{~h}$ recoveries of $\mathrm{NH}_{3}$ were recorded over that period. After to days complete recovery of the infused $\mathrm{NH}_{3}$ was obtained. In Fig. 2 the $\log _{10}$ of $\mathrm{NH}_{3}$ unrecovered in the chamber has been plotted against time after infusion. For the first 6 days the decline in unrecovered $\mathrm{NH}_{3}$ was exponential, the half-life being $2 \cdot 26$ days in this experiment. In a similar experiment in another apparatus the half-life was 3.70 days.

Even with no infusion of $\mathrm{NH}_{3} \mathrm{~N}$ and no sheep in the apparatus, a small amount of $\mathrm{NH}_{3}$ was invariably recovered, e.g. $3.7 \mathrm{mg} \mathrm{N}$ were recovered on the day before the infusion in the experiment recorded in Fig. 2. These small blank values were due to the very slow recovery of $\mathrm{NH}_{3}$ liberated on previous occasions, adsorbed at some 
unicentified part of the apparatus and subsequently slowly released over a long period of time.

Sheep cannot be left in the respiration apparatus for more than $24 \mathrm{~h}$ without the apparatus being opened to remove faeces and urine and to provide food. A number of $24 \mathrm{~h} \mathrm{NH} \mathrm{NH}_{3}$ recovery experiments were therefore made to see if reasonably consistent results could be obtained. The chamber was run until a low $\mathrm{NH}_{3}$ blank was obtained. Clean harness for the sheep was in the chamber throughout. The recovery experiment was then made as already described. Results of eight experiments are given in Table 3. The average recovery was $50.3 \pm \mathrm{I} \cdot 4 \%$ (standard error of mean) of the $\mathrm{NH}_{3}$ released. The coefficient of variation was $7.99 \%$.

\section{Table 3. Recovery of $\mathrm{NH}_{3} \mathrm{~N}$ infused into a respiration chamber} in eight single 24 h experiments

\begin{tabular}{|c|c|c|c|c|c|c|c|}
\hline & $\begin{array}{l}\text { Released } \\
\text { in } \\
\text { chamber }\end{array}$ & $\begin{array}{c}\text { Recovered } \\
\text { in } \\
\text { absorption } \\
\text { train }\end{array}$ & $\begin{array}{c}\text { Recovered } \\
\text { in } \\
\text { volatile } \\
\mathrm{NH}_{3} \text { traps }\end{array}$ & Total & $\begin{array}{l}\text { Preceding } \\
\text { day's } \\
\text { blank } \\
\text { correction }\end{array}$ & $\begin{array}{l}\text { Corrected } \\
\text { n recovery }\end{array}$ & $\begin{array}{l}\text { Recovered } \\
(\%)\end{array}$ \\
\hline Expt no. & \multicolumn{7}{|c|}{ (mg) } \\
\hline I & 100.7 & $47 \cdot 9$ & $I \cdot 2$ & $49^{\circ} \mathrm{I}$ & $\mathrm{I} \cdot 8$ & $47 \cdot 3$ & $47^{\circ} \mathrm{O}$ \\
\hline 2 & 1027 & 55.4 & $I \cdot 5$ & $56 \cdot 9$ & 3.0 & 53.9 & $5^{2} \cdot 6$ \\
\hline 3 & $105^{\cdot} \cdot \mathrm{I}$ & $48 \cdot 7$ & 10 & $49 \cdot 7$ & 30 & $46 \cdot 7$ & $44 \cdot 5$ \\
\hline 4 & $99 \cdot 7$ & 57.5 & 10 & $5^{8 \cdot 5}$ & $6 \cdot 2$ & $52 \cdot 3$ & $52 \cdot 5$ \\
\hline 5 & 114.7 & $67 \cdot 3$ & $1 \cdot 7$ & 69.0 & 9.4 & $59 \cdot 6$ & $5^{1} \cdot 9$ \\
\hline 6 & $228 \cdot 2$ & 1380 & - & $\mathrm{I}_{3} 8^{8} \cdot 0$ & $7 \cdot 2$ & 130.8 & $57 \cdot 3$ \\
\hline 7 & $151^{1} \cdot 7$ & $79 \cdot 5$ & - & 79.5 & $8 \cdot I$ & $71 \cdot 4$ & $48 \cdot 3$ \\
\hline 8 & I 34.5 & $72 \cdot 8$ & $2 \cdot 2$ & $75^{\circ} \circ$ & $9 \cdot 6$ & $65 \cdot 4$ & $48 \cdot 6$ \\
\hline
\end{tabular}

This recovery factor of $50.3 \%$ was used to estimate the total release of $\mathrm{NH}_{3}$ from sheep in further experiments conducted in the same way. The sheep were harnessed with the clean harness after removing any wool around the penis which would interfere with satisfactory urine collection. Urine was collected into $40 \mathrm{ml}$ of $\mathrm{N}_{-} \mathrm{H}_{2} \mathrm{SO}_{4}$, and urine volatile $\mathrm{NH}_{3}$ was trapped in acid traps. The urine pumps were run continuously so a small amount of the $\mathrm{NH}_{3}$ retained in the volatile $\mathrm{NH}_{3}$ acid trap could arise from the chamber air rather than from the urine. In six of the $\mathrm{NH}_{3}$ recovery experiments recorded in Table 3 the urine pump was run with a volatile $\mathrm{NH}_{3}$ trap in place and the percentage of total $\mathrm{NH}_{3}$ recovered retained in the respiration chamber absorption train trap calculated. The position of the urine volatile $\mathrm{NH}_{3}$ trap and the acid traps in the respiration chamber absorption train are illustrated in Fig. I. This recovery was $97.6 \pm 0.1 \%$ (mean and standard error) of the sum of the $\mathrm{NH}_{3}$ retained in the volatile $\mathrm{NH}_{3}$ trap and the acid flasks in the respiration chamber absorption train. To allow for the $\mathrm{NH}_{3}$ of chamber air absorbed in the volatile $\mathrm{NH}_{3}$ trap when experiments were conducted with sheep in the respiration chamber, the $\mathrm{NH}_{3}$ recovered in the absorption train flasks was divided by 0.976 .

The total loss of $\mathrm{NH}_{3}$ from sheep was determined in eleven experiments, the results of which are given in Table 4 . The recovery control experiments recorded in Table 3 were made either before or at intervals between determinations of the $\mathrm{NH}_{3}$ loss from 
sheep, the same respiration chamber being used throughout. At least three or four blank $24 \mathrm{~h}$ runs were required before recovery of $\mathrm{NH}_{3}$ was determined, and the final $\mathrm{NH}_{3}$ blank was subtracted from that obtained from the sheep or from the $\mathrm{NH}_{3}$ recovery experiment. The resulting figure divided by $0.5 \circ 3$ gave the amount of $\mathrm{NH}_{3}$ lost during the day.

Table 4. Dermal and other losses of $\mathrm{NH}_{3} \mathrm{~N}$ from sheep per $24 h$

\begin{tabular}{|c|c|c|c|c|c|c|}
\hline Sheep & $\begin{array}{c}\text { Weight } \\
\text { (kg) }\end{array}$ & $\begin{array}{l}\text { Total } \\
\mathrm{NH}_{3} \mathrm{~N}^{*} \\
\text { collected } \\
\quad(\mathrm{mg})\end{array}$ & $\begin{array}{c}\text { Previous } \\
\text { blank } \\
\mathrm{NH}_{3} \mathrm{~N} \\
(\mathrm{mg})\end{array}$ & $\begin{array}{c}\mathrm{NH}_{3} \mathrm{~N} \\
\text { recovered } \\
(\mathrm{mg})\end{array}$ & $\begin{array}{l}\text { Calculated } \dagger \\
\text { production } \\
\text { of } \mathrm{NH}_{3} \mathrm{~N} \\
(\mathrm{mg})\end{array}$ & $\begin{array}{c}\mathrm{NH}_{3} \mathrm{~N} \text { lost } \\
\text { in } 24 \mathrm{~h} \\
\text { (mg/kg } \\
\text { body-weight) }\end{array}$ \\
\hline $\mathrm{R}_{2}$ & $38 \cdot 5$ & 16.8 & $5 \cdot 2$ & II $\cdot 6$ & $23 \cdot 1$ & 0.60 \\
\hline $\mathrm{R}_{3}$ & $40 \cdot 3$ & $74^{\prime} 9$ & 3.8 & $7 \mathrm{I} \cdot \mathrm{I}$ & 1412 & 3.50 \\
\hline $\mathrm{R}_{3}$ & $39 \cdot 2$ & $87 \cdot I$ & $3 \cdot 7$ & 83.4 & 165.8 & $4 \cdot 23$ \\
\hline$W_{I}$ & 54.5 & 59.0 & $2 \cdot 2$ & $56 \cdot 8$ & 112.9 & 2.07 \\
\hline$W_{3}$ & $52 \cdot 1$ & $62 \cdot 6$ & $5 \cdot 1$ & 57.5 & I 14.2 & $2 \cdot 19$ \\
\hline$W_{4}$ & 53.4 & $86 \cdot 4$ & $2 \cdot 5$ & $84^{\circ} \circ$ & x66.9 & 3.13 \\
\hline $\mathrm{B}_{2}$ & $55^{\circ} \mathrm{I}$ & $224 \cdot 2$ & $6 \cdot 3$ & $217 \cdot 9$ & $427 \cdot 0$ & $7 \cdot 76$ \\
\hline $\mathrm{B}_{3}$ & $6 I \cdot 2$ & 70.9 & $7 \cdot 5$ & $63 \cdot 4$ & 126.1 & $2 \cdot 06$ \\
\hline $\mathbf{B}_{3}$ & 63.0 & 1349 & 10.4 & 124.5 & $247 \cdot 4$ & 3.93 \\
\hline YI & $65 \cdot 5$ & $90 \cdot 2$ & 4.4 & $85 \cdot 8$ & 170.4 & $2 \cdot 60$ \\
\hline$Y_{4}$ & $67 \cdot 5$ & I 12.2 & 4.9 & $108 \cdot 3$ & 213.2 & $3 \cdot 16$ \\
\hline
\end{tabular}

* $\mathrm{NH}_{3} \mathrm{~N}$ recovered in absorption train corrected for that absorbed in volatile $\mathrm{NH}_{3}$ trap. See p. 332 . + Calculated on the assumption of $50 \cdot 3 \%$ recovery from $\mathrm{NH}_{3}$ released.

\section{The loss of $\mathrm{NH}_{3}$ from skin and fleece}

In two experiments, painted tin boxes were strapped on to the sheep's back and the $\mathrm{NH}_{3}$ lost per $24 \mathrm{~h}$ was measured as already described. Losses from a $48 \cdot 7 \mathrm{~kg}$ sheep were 35.9 and $14.6 \mathrm{mg} \mathrm{NH}_{3} \mathrm{~N}$ on the two occasions.

\section{The $N$ content of suint}

Water extracts of two samples of wool were analysed and the suint was found to contain, on a dry-matter basis, an average of $2.77 \% \mathrm{~N}$, the partition of the $\mathrm{N}$ being $7.6 \%$ as $\mathrm{NH}_{3}, 44.0 \%$ as urea, $\mathrm{I} 6.6 \%$ as protein and (by difference) $31.8 \%$ as unidentified non-protein $\mathrm{N}$.

\section{DISCUSSION}

Loss of $\mathrm{N}$ not normally taken into account in balance experiments has been divided into two major categories. First, loss of $\mathrm{N}$ from the faeces and urine between their voiding and their collection and analysis and, secondly, loss of $\mathrm{N}$ from other sources, notably from the mouth, expired air and skin.

Loss of $\mathrm{NH}_{3}$ from faeces during the interval between their excretion and analysis was found to be negligible. Loss of $\mathrm{NH}_{3}$ from urine could, however, on occasions be considerable. Collection into a neutral preservative considerably increased the loss, but even with collection into acid preservative the loss was found to vary between extremes of 17 and $770 \mathrm{mg} \mathrm{NH} /$ N/day largely owing to the $\mathrm{NH}_{3}$ of the urine remaining in the collecting tubes and funnels. The loss increased with increasing environ- 
mental temperature and may also have been affected by factors such as frequency of urination, bacteria on utensils, the proportion of preformed $\mathrm{NH}_{3} \mathrm{~N}$ in the urinary $\mathrm{N}$ excreted and the $\mathrm{pH}$ of the urine as excreted. It is thus not possible to predict the proportion of collected urinary $\mathrm{N}$ lost as volatile $\mathrm{NH}_{3}$; it must be determined directly.

The second category of $\mathrm{NH}_{3}$ loss was determined in the respiration chamber. The total loss of $\mathrm{NH}_{3}$ determined in this way included the loss of $\mathrm{NH}_{3}$ from the faeces, which has been shown to be negligible, that from expired air and eructed gas including $\mathrm{NH}_{3}$ production in the mouth, and the dermal loss of $\mathrm{NH}_{3}$. Volatile $\mathrm{NH}_{3}$ loss arising from the urine collection apparatus associated with the respiration chamber was excluded because a small acid trap prevented contamination from this source.

The loss of about I mg $\mathrm{NH}_{3} \mathrm{~N} / 24 \mathrm{~h}$ in expired air is of a similar order to that found by Jacquez, Poppell \& Jeltsch (1959) for the dog. Even with high rumen $\mathrm{NH}_{3}$ levels, there was no increase in loss when expired air plus eructed gas were collected, so there can have been little loss of $\mathrm{NH}_{3}$ gas from the rumen or from the mouth as a result of bacterial hydrolysis of salivary urea.

Two correction factors were applied to the $\mathrm{NH}_{3}$ recovered in the absorption vessels to calculate the total $\mathrm{NH}_{3}$ loss in the respiration chamber. The first was subtraction of the previous day's $\mathrm{NH}_{3}$ blank from the total recovered, and the second was the division of this amount by $50 \cdot 3 \%$ to correct for the recovery of $\mathrm{NH}_{3}$ released in the chamber during a $24 \mathrm{~h}$ period. In the apparatus used in these experiments the decline in unrecovered $\mathrm{NH}_{3}$ with time was exponential, the half-life being 3.70 days after the termination of a continuous release of $\mathrm{NH}_{3}$ for $24 \mathrm{~h}$. The same apparatus was used throughout to minimize variations in recovery. After an experiment the chamber was run until the $\mathrm{NH}_{3}$ blank was low; in the experiments recorded in Table 4 the average blank was $5.08 \mathrm{mg} \mathrm{N} / 24 \mathrm{~h}$. Application of this correction introduced little error, because, although the blank value was itself declining, the day-to-day change was only of the order of $\mathrm{I}-2 \mathrm{mg} \mathrm{N} / 24 \mathrm{~h}$ at this level. The cause of the long retention of released $\mathrm{NH}_{3}$ was not discovered. It was not due to absorption of $\mathrm{NH}_{3}$ by the silica gel used to remove water vapour from the chamber, for this was positioned beyond the very efficient $\mathrm{NH}_{3}$ trap. (Silica gel will absorb large amounts of $\mathrm{NH}_{3}$ which is not released unless it is heated; Martin (1964) unpublished.) It was not due to solution of $\mathrm{NH}_{3}$ in water in the chamber because the chambers were dry and water bowls were disconnected. If the apparatus was left closed, complete recovery of $\mathrm{NH}_{3}$ was obtained after I0-12 days, suggesting some process of absorption and subsequent release of $\mathrm{NH}_{3}$ from the walls of the chamber or associated pipework.

In Table 5 the average total $\mathrm{NH}_{3}$ loss recorded for sheep receiving each diet has been related to their body-weight and surface area. On either of these bases the loss was not related to food intake. The average loss over $24 \mathrm{~h}$ for all feeding levels was $3.14 \mathrm{mg} \mathrm{N} / \mathrm{kg}$ body-weight, which is similar to an average amount of $3.8 \mathrm{mg} / \mathrm{kg}$ which Harris \& Mitchell (I94I) recovered by washing sheep each day. These workers also found that the amount of $\mathrm{N}$ consumed had no effect on the magnitude of the loss. The $95 \%$ fiducial limits of the mean loss of $\mathrm{N} / \mathrm{kg}$ were $1 \cdot 9 \mathrm{I}-4 \cdot 36 \mathrm{mg} \mathrm{N} /$ day.

In the absence of contamination from any other source, the total $\mathrm{NH}_{3}$ loss must refer to loss of $\mathrm{N}$ from the skin and fleece in sweat or 'suint'. Daly \& Carter (I955) 
found suint production to be dependent on food intake and this result has been confirmed by J. L. Clapperton (1965, personal communication) with the sheep used in this experiment. A patch $(10 \times 10 \mathrm{~cm})$ on each mid-side of each sheep was clipped every 28 days. On the assumption that surface area is related to body-weight by the equation $0.09 \mathrm{~kg} W^{0.67}$ and that suint production in the clipped patch of $100 \mathrm{~cm}^{2}$ is representative of that over the whole animal, suint production per $\mathrm{kg}$ body-weight per day can be calculated. For sheep consuming diets R, W, B and Y (p. 328), 21 $\cdot 2,44 \cdot 6$, 65.6 and $91.2 \mathrm{mg}$ suint per $\mathrm{kg}$ body-weight per day were produced respectively. The suint was found to contain $2.8 \% \mathrm{~N}$. The $\mathrm{N}$ lost per day would be, accordingly, $0.59, \mathrm{I} \cdot 25, \mathrm{I} \cdot 84$ and $2.55 \mathrm{mg} / \mathrm{kg}$ body-weight respectively with the four diets. Sheep $\mathrm{R}_{1}, \mathrm{~B}_{3}$ (first experiment only) and $\mathrm{Y}_{\mathrm{I}}$ had total $\mathrm{NH}_{3}$ losses per day of $0.60,2.06$ and $2.60 \mathrm{mg} / \mathrm{kg}$ body-weight which are close to the calculated values of $0.58,1.84$ and $2.55 \mathrm{mg} \mathrm{N}$ for the diets consumed. Results for other sheep were all greater by varying degrees than the values calculated. In fact, variation between experiments was much larger than that predicted from difference in food intake which suggests that some factor other than excretion from the skin was responsible for part of the loss in some experiments.

Table 5. Dermal and other $\mathrm{NH}_{3}$ losses in sheep, expressed per kg body-weight and per $m^{2}$ body surface

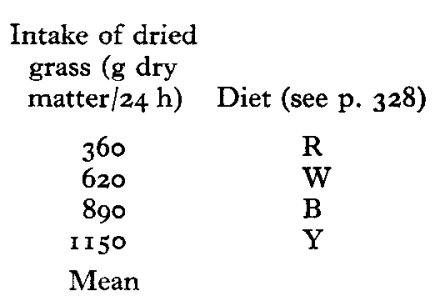

$\begin{array}{ccc}\begin{array}{c}\text { Average loss of } \\ \text { No. of } \\ \text { experiments }\end{array} & \begin{array}{c}\mathrm{NH}_{3} \mathrm{~N} \text { in 24 } \mathrm{h} \\ (\mathrm{mg} / \mathrm{kg} \\ \text { body-weight) }\end{array} & \begin{array}{c}\text { Average loss of } \\ \mathrm{NH}_{3} \mathrm{~N} \text { in 24 } \mathrm{h} \\ \left(\mathrm{mg} / \mathrm{m}^{2}\right)\end{array} \\ 3 & 2.528 & 103.4 \\ 3 & 2.796 & 101.7 \\ 3 & 4.581 & 194.3 \\ 2 & 2.884 & 127.8\end{array}$

* Means and standard errors of means.

In two experiments the loss of $\mathrm{NH}_{3}$ from sheep fleece was measured by placing a box over an area of fleece and measuring the $\mathrm{NH}_{3}$ loss per $24 \mathrm{~h}$. The loss from a $500 \mathrm{~cm}^{2}$ area of the sheep's back was small, equivalent to 0.30 and $0.80 \mathrm{mg} \mathrm{N} / \mathrm{kg}$ body-weight per day. The sheep was eating a diet similar to $\mathrm{W}$ for which the calculated dermal loss per day was $\mathrm{I} \cdot 84 \mathrm{mg} \mathrm{N} / \mathrm{kg}$ body-weight. Suint production may vary in different parts of the body causing variable results when small areas are measured, and possibly not all suint $\mathrm{N}$ is lost as $\mathrm{NH}_{3}$, which may explain the small amount of $\mathrm{NH}_{3}$ recovered.

The very much lower losses of $\mathrm{NH}_{3}$ from the back of the sheep than from the whole animal suggest that contamination of the fleece with urine may be responsible for the losses observed. In only one of the eleven sheep experiments was the fleece noticeably wet with urine, and the floor of the chamber was never damp. Sheep B 2, however, had spilt some urine on his fleece and the $\mathrm{NH}_{3}$ loss from this sheep was the largest recorded, $427 \mathrm{mg} \mathrm{N} / 24 \mathrm{~h}$. It is concluded, therefore, that the wide variation in $\mathrm{NH}_{3}$ 
loss was due to slight errors in urine collection in some experiments which masked any effect that diet would have had.

An estimate has been made in Table 6 of the average loss of $\mathrm{NH}_{3}$ not normally taken into account for sheep receiving rations of increasing protein content. Average values found in these experiments have been used for the two catego ries of $\mathrm{NH}_{3}$ loss, and the percentage reduction in apparent $\mathrm{N}$ balance has been recorded. The analytical error involved in the computation of $\mathrm{N}$ balance was assessed by calculating the standard error, expressed as a percentage of the mean, for groups of thirty-five recent analyses. The errors for food, faeces and urine determinations were $\pm 0.25, \pm \mathrm{I} \cdot 04$ and $\pm 0.54 \%$ respectively. Applied to the experiments recorded in Table 6 the apparent balances with the cumulative analytical error become $-\mathbf{I} \cdot 96 \pm 0.06,+0.37 \pm$ $0.1 \mathrm{I},+\mathrm{I} .54 \pm 0.09$ and $+5.35 \pm 0.4 \mathrm{I} \mathrm{N} /$ day. The analytical errors expressed as a percentage of the estimated losses of $\mathrm{N}$ in faeces and urine were $0.5,0.7,0.6$ and 0.6 respectively. The corrections applied to the $\mathrm{N}$ balance expressed as a percentage of the estimated $\mathrm{N}$ losses in faeces and urine were $2 \cdot 6,2 \cdot 0, \mathrm{I} \cdot 4$ and $\mathrm{I} \cdot 2 \%$ respectively for the same experiments recorded in Table 6 and were inversely related to $\mathrm{N}$ intake.

Table 6. Effect of errors in the recovery of $\mathrm{NH}_{3}$ on nitrogen balance in sheep given different diets

\begin{tabular}{|c|c|c|c|c|c|c|c|c|}
\hline \multirow[b]{2}{*}{ Diet } & \multirow[b]{2}{*}{$\begin{array}{l}\text { Weight } \\
\text { of } \\
\text { sheep } \\
\text { (kg) }\end{array}$} & \multirow[b]{2}{*}{$\begin{array}{l}\mathrm{N} \\
\text { intake } \\
\text { (g/day) }\end{array}$} & \multirow[b]{2}{*}{$\begin{array}{l}\text { Faeces } \\
N \\
(\mathrm{~g} / \text { day })\end{array}$} & \multirow[b]{2}{*}{$\begin{array}{l}\text { Urine } \\
\underset{(\mathrm{g} / \text { day })}{N}\end{array}$} & \multicolumn{3}{|c|}{ Correction } & \\
\hline & & & & & $\begin{array}{c}\text { Apparent } \\
\text { balance } \\
\text { (g/day) }\end{array}$ & $\begin{array}{c}\text { Urine } \\
\text { t volatile } \\
\mathrm{NH}_{3} \mathrm{~N}^{*} \\
\text { (g/day) }\end{array}$ & $\begin{array}{l}\text { Other } \\
\mathrm{NH}_{3} \mathrm{~N} \dagger \\
\text { (g/day) }\end{array}$ & $\begin{array}{l}\text { Corrected } \\
\text { balance }\end{array}$ \\
\hline $\begin{array}{l}\text { Hay, maintenance ration } \\
\text { only }\end{array}$ & $68 \cdot 6$ & $9 \cdot 2$ & $4 \cdot I$ & $7 \cdot \mathrm{I}$ & $-2 \cdot 0$ & 0.07 & 0.22 & $-2 \cdot 3$ \\
\hline Hay (ad lib.) & $73 \cdot I$ & 15.6 & $8 \cdot 4$ & $6 \cdot 8$ & +0.4 & 0.07 & 0.23 & $+0 . I$ \\
\hline $\begin{array}{l}\text { Hay plus decorticated } \\
\text { groundnut meal, main- } \\
\text { tenance ration only }\end{array}$ & $6 \mathrm{r} \cdot 2$ & 34.9 & $4 \cdot 2$ & $29 \cdot 2$ & $+1 \cdot 5$ & 0.28 & 0.19 & $+\mathbf{I} \cdot \mathbf{I}$ \\
\hline $\begin{array}{l}\text { Hay plus decorticated } \\
\text { groundnut meal (ad lib.) }\end{array}$ & $70 \cdot 9$ & $78 \cdot 5$ & $9 \cdot 7$ & 63.5 & $+5 \cdot 3$ & 0.62 & 0.22 & +4.5 \\
\hline
\end{tabular}

I thank Dr K. L. Blaxter for helpful discussions during the course of this work. I am grateful also to Miss R. Caldwell for analytical assistance and to other members of the Nutrition Department for assistance in the conduct of the respiration chamber experiments. 


\section{REFERENCES}

Allison, J. B. \& Bird, J. W. C. (1964). In Mammalian Protein Metabolism. Vol, I, p. 483. [H. N. Munro and J. B. Allison, editors.] New York and London: Academic Press Inc.

Bock, H. D., Nehring, K., Schiemann, R., Hovorka, F., Horszczaruk, F. \& Angelowa, L. (1964). Arch. Tierernähr. 14, 13.

Butterworth, M. H. (I963). F. Sci. Fd Agric. 13, 6.

Crowther, A. B. \& Large, R. S. (1956). Analyst, Lond., 81, 64.

Daly, R. A. \& Carter, H. B. (1955). Aust. Y. agric. Res. 6, 476.

Harris, L. E. \& Mitchell, H. H. (194I). F. Nutr. 22, I67.

Henry, K. M. (1965). Br. F. Nutr. 19, 25.

Jacquez, J. A., Poppell, J. W. \& Jeltsch, R. (I959). Science, N.Y., I29, 269.

Nehring, K. (1957). Biochem. Z. 328, 549.

Tetlow, J. A. \& Wilson, A. L. (1964). Analyst, Lond., 89, 453.

Van Slyke, D. D. \& Cullen, G. E. (1914). F. biol. Chem. I9, 2 I I.

Wainman, F. W. \& Blaxter, K. L. (1958). Publs Eur. Ass. Anim. Prod. no. 8, p. 80.

Wainman, F. W. \& Paterson, D. (1963). F. agric. Sci., Camb., 6r, 253. 